\title{
FATHOM
}

\section{Introduction: Objects in Hardy and Conrad}

Introduction : les objets chez Hardy et Conrad

\section{Annie Ramel}

\section{OpenEdition}

\section{Journals}

Electronic version

URL: http://journals.openedition.org/fathom/882

DOI: $10.4000 /$ fathom. 882

ISSN: 2270-6798

\section{Publisher}

Association française sur les études sur Thomas Hardy

\section{Electronic reference}

Annie Ramel, «Introduction: Objects in Hardy and Conrad », FATHOM [Online], 6 | 2019, Online since 01 October 2019, connection on 14 October 2019. URL : http://journals.openedition.org/fathom/882 ; DOI : $10.4000 /$ fathom.882

This text was automatically generated on 14 October 2019 . 


\title{
Introduction: Objects in Hardy and Conrad
}

\author{
Introduction : les objets chez Hardy et Conrad
}

\author{
Annie Ramel
}

1 According to The Concise Oxford Dictionary, an "object" is "a thing placed before the eye or presented to one of the senses". The word comes from the Latin objectum, itself derived from objicere, which means "to throw" (jacere) "before" (ob). An "object", whether an artefact or not, may be put to some purpose. But the object, as "thrown before" the subject, as a "person or thing to which action or feeling is directed", may also refer to the thing aimed at by human desire. Therefore the object is not just what is owned, or could be owned, but also what one desires.

2 The life of objects extends over the years, sometimes over millennia, during which they become loaded with meaning and memories. They can be exhumed, like the "Druid Stone" buried three feet deep in the earth at Max Gate, which Hardy discovered, brought to the surface, and exhibited in his garden. In his mind, it was undoubtedly associated with Stonehenge, a fact which J.B. Bullen uses as a starting-point for his paper on "Thomas Hardy's Tess of the d'Urbervilles, Apollo, Dionysus, and Stonehenge". The paper focuses on a dialectic between Apollo, the sun god, and Dionysus, the chthonic god of the underworld, where the harp-playing Apollo is figured by Angel Clare and Dionysus by Alec d'Urberville, whose cigar looks like a "phallic thyrsus". It concludes with a parallel between two scenes: the violation of Tess by Alec d'Urberville/Dionysus in the forest of The Chase, which anticipates the "imminent immolation" of Tess at Stonehenge, viewed as a sacrifice to the sun god. Both Dionysus and Apollo "surfeit" on the object offered to them in sacrifice: Tess.

Objects may be a trace of bygone civilizations left in the present, or the productions of an age when "commodity culture" was beginning to spread, not just in Victorian England, but all over the world, at a time when "the sun never set on the British Empire". Such objects can be given, exchanged, sold, in complex circulations of meaning and emotions. Robert Hampson, in his paper on "Conrad's Objects", focuses on objects as cultural artefacts, seen in an ethnographic perspective, and on the trading 
networks through which commodities are exchanged in Conrad's fiction. The article shows "the pervasiveness of commodity culture" in an inter-related, globalized world, of which Conrad had a first-hand experience. It also shows how those objects were sometimes recoded, recycled, in various forms of "cultural detournement". Hampson goes further when he considers the object as fetish, and notes the sense of "hollowness" which overcomes the characters when their fetish objects lose their magical power. The paper ends with another form of magical thinking: "charms and talismans", which can be given and thus have power in a man's life. But to be able to relate what Yael Levin calls "the otherwise present" (Levin quoted by Hampson) - like haunting, ghosts, hallucinations - the writer needs a power of imagination that goes beyond the techniques that could be learnt from Flaubert.

4 With Hardy, and then with Conrad, the nineteenth century was drawing to a close. In the Victorian era, especially after the Great Exhibition of 1851, objects multiplied in the daily life of English people. Homes became cluttered with decorative objects, and Victorian novels were said to be "crowded novels" (Brown 1986, 786-794), filled with a multitude of useless details or objects. Victorian realism has often been associated with an aesthetics where fullness prevails, in which proliferating objects come to punctuate the narrative, thus producing numerous effets de réel. Yet those objects can be powerfully symbolic, they can serve as metonyms, or metaphors, which represent personalities, situations, ideological positions. Dickens used them as elements of characterization, revealing the psychology of his characters, sometimes producing micro-comical effects.

5 But Hardy and Conrad wandered between two worlds, the nineteenth and the twentieth centuries - one drawing to a close, the other attempting to be born, to paraphrase Matthew Arnold's verse in "Stanzas from the Grande Chartreuse" ${ }^{1}$. And it seems that objects in their texts have a different modus operandi from that of earlier writers. Indeed Flaubert's verisimilitude is not enough to capture "the otherwise present" (R. Hampson). Several articles published in this volume point to a punctum effect that objects produce in the studium of representation, blurring signification, redirecting the reader's gaze, in an aesthetics which is radically different from that of Dickens. Catherine Lanone, analyzing the scene in the church where Troy is to be married to Fanny, in Far from the Madding Crowd, sees the quarter-jack as a punctum in the studium of reality. Similarly, Jim's vision of reality in Lord Jim is made unreadable by unexpected details that produce a punctum effect, while the "strange noise" that he hears on the Patna functions like an auditory punctum (S. Bernard). The "bit of white worsted" the dying man has tied round his neck in Heart of Darkness is an apparently insignificant detail, but according to Nathalie Martinière it works as a punctum shooting out of the studium of the text, pricking, piercing, bruising the reader (Barthes 26) as it confronts him to some repressed, unbearable truth - the truth about colonialism and its crimes. Similarly, the "disruptive presence" of objects such as the "glaringly white" shirt and cuffs of the accountant, the dominoes on board the Nellie, the piano-keys at the Intended's in Brussels, form a subtext which re-introduces the human element into the picture and forces the reader to consider the ethical and moral questions raised by the novella. Though seemingly unimportant background details, they are essential in Conrad's aesthetic strategy.

Indeed objects in Hardy and Conrad have the power to make us see and hear what the text in its discursive dimension fails to show. That point is made by Adrian Grafe in his 
paper on Human Shows, Hardy's penultimate poetry volume. The article deals with Hardy's deep sense of the "aliveness" of objects (Winnicott, quoted by Grafe) - objects which may speak in Hardy's poems, or be addressed to by the speaker of the poem. They may seem to be insignificant details, but under their frozen outer surface they have a life of their own which means a lot to the poet. They both serve as metaphors and as realia linking the poet to the phenomenal world. Hardy "particularizes" them, he takes them as they are, in sheer wonder at their density and vividness, which inspire his "poetics of wonder".

7 If, beyond their "immediacy" (A. Grafe), objects point to some truth that lies beneath the surface of the text, could it not be argued that they have the power to make visible the invisible? The idea is developed by Isabelle Gadoin in her paper on looking-glasses, inspired by Merleau-Ponty's ideas on visibility/invisibility. There is more than meets the eye in Hardy's looking-glasses: instead of providing the onlooker with the perfect image of a unified self, they work as "hour-glasses", like Vanities, and they also allow moments of "unvision" when the subject glimpses the enigma of his subjective division. In fact the glass "abstracts" human subjects into shadows, it "empties out the universe" as it shows it peopled with phantoms.

8 The question then is: what is that thing pointed out by objects in literature, the "thing that lies beneath the semblance of the thing" (Woolf 138), the "deep hidden truthfulness" (Conrad 168), "the heart and inner meaning" of things, which art makes "vividly visible" (Hardy 183)? For if something transcends the material reality of objects, what may be visioned - or unvisioned - in that beyond? What is the essence of the "invisibility" that the visible both conceals and reveals? In George Herbert's Anglican hymn ("The Elixir"), it was a vision of Heaven that could be glimpsed (I. Gadoin). In those days, the presence of some transcendent reality was conceived as the equivalent of Kant's "supra-sensible thing". But with Hegel (and with Conrad), "the transcendent presupposition has vanished into thin air", "the truth of the suprasensible thing is just appearance as appearance" (Josiane Paccaud). Conrad "finds no salutary hope in transcendence" (S. Bernard). The First Cause is not a caring God but an indifferent knitting machine for which "nothing matters" (Ian Watt, quoted by Bernard). According to Žižek, the sublime points to a void, "the pure Nothing of absolute negativity" (Žižek 1989, 206). Hegel calls that abyss "the night of the world" (Žižek 1999, 136). For Conrad, that "thing of nothing" (Paccaud) is "a depth of horrible void".

9 That unfathomable void is at the core of several articles in this volume: in Stéphanie Bernard's article it is the "vain gloriousness" of the Titanic in Hardy's poem "The Convergence of the Twain". A parallel is drawn between "the spinner of the years", which has caused the disaster, and Conrad's "knitting machine". Hardy's poem conveys a vision of "human vanity", i.e. of emptiness (in the etymological sense of "vanity"), as it is about a radical, irremediable loss, the loss of an object which is "forever unreachable in this realm of death" (Bernard).

In her study of timepieces, Catherine Lanone opposes the "ecology of kairos" (as exemplified by Gabriel Oak's skilful handling of communal and organic time in Far from the Madding (rowd) to Jim's inability to act at the right moment in Lord Jim. After the fatal jump ("an anti-kairotic moment"), a "temporal faultline" opens between before and after, an abyss which makes Jim feel as if he "had jumped into a well - into an everlasting deep hole" (Conrad 70). What has happened is "a drama of no-thing" 
(Paccaud, quoted by Lanone), a "temporal vortex" that the text can only circle round. Thus it appears that the fullness, the solidity of the Victorian world, crowded with a profusion of material objects, turns into some bottomless void in the writings of our two authors.

In The Sublime Object of Ideology, Žižek (following Lacan) distinguishes between three types of objects of desire: first, "the object cause of desire", which we must leave behind and whose very absence sets desire into motion. Should it fail to be a radical absence, a missing object that may be replaced by another, it would block the metonymy of desire and lead to tragedy. In "Karain" it is embodied by Karain's mother and the Queen of England (Josiane Paccaud). In Far from the Madding Crowd, Bathsheba is "the object cause" of Boldwood's desire. The second object, a "massively intrusive presence, the mute embodiment of impossible jouissance" (Paccaud), is the Lacanian object-gaze and object-voice, which may haunt a character's life if it ceases to be an evanescent punctum and turns into a permanent fixture in his/her reality. Annie Ramel's article on "gaze and voice as surplus objects in The Mayor of Casterbridge" deals with such an object. So does Paccaud's article, in its handling of voice and gaze (the voice and the sunken eyes of Matara's ghost pursuing Karain). The logical outcome of this disorder is the destruction of social links: Henchard becomes alien to his community, and only death can ensue, with the absolute silence reached at the end of the novel. Žižek's third variety of the object makes possible a restoration of the symbolic order: in "Karain", it is the gilt sovereign, the jubilee sixpence, a portable object of exchange in the image of the Queen of England, which is "a mere semblance for an absence" (Paccaud). Yet that insignificant leftover stabilizes the cruel gaze and hushes the haunting voice. Bernard also writes about Conrad's characters who need to cling to objects (like the sovereign in "Karain") as well as to "the salutary value of work", which saves them "from the devouring terror of emptiness".

Viewing human beings as phantoms, mere shadows in the "night of the world", raises the issue of the relation between subject and object: what becomes of subjects when machines take the lead over men and turn them into objects (Bernard)? Andrew Hewitt approaches the question by his study of weapons in the novels of Hardy and Conrad: domestic objects (like carving-knives) are turned into lethal weapons in Tess of the d'Urbervilles and The Secret Agent - and conversely weapons used in combat may find their way into the domestic sphere. The uncanny, the unheimlich, springs from this blurring of boundaries, the intrusion of the strange into the familiar. Rather strangely, those weapons make their appearance "without warning", "out of nowhere", they are "added" to the scene after they have been used, in a reconstruction of events. They seem to be in excess of reality ${ }^{3}$. The question, then, is: would it be possible for those objects to have an agency of their own? Could they be so full of uncontrollable life that they might be part of what Jane Bennett calls "vibrant matter"?

The misuse of domestic objects - like the carving-knife used as a weapon by Tess - is also mentioned by Ludovic Le Saux, who stresses not so much the unheimlich aspect of such misemployment as its symbolic value: for it is emblematic of Tess's failure to fit into the domestic mould of "The Angel in the House". Le Saux makes this point by focusing on Hardy's reappropriation of the tradition of Golden Age Dutch painting, in an ironic perspective which parodies the genial atmosphere of that genre. Hardy's highly visual descriptions are reminiscent of Vanitas paintings, as they suggest the vanity of human existence and contribute to the tragic tone of the novel. Thus the 
novel is "progressively emptied of human presence" (Le Saux) - absence par excellence being rendered by the image of the two vacated chairs on the morning after Tess has told her story. Again we find ourselves in "the night of the world", and again the question raised by "the vain gloriousness" of human life concerns the relation between subjects and objects: as subjects are nullified, objects become subjects, ${ }^{4}$ they invade the scene and become powerfully present.

Jane Thomas focuses on the footprint in Hardy's The Woodlanders and Joseph Conrad's Almayer's Folly. The paper shows how such "irrelevant details" (J.H. Miller) are not just "objects" but "things", whose "thingness" comes from their being in excess of reality, in a close relationship to a subject. Objects such as fetishes, idols, totems, etc., may be called "things" because their value for a particular subject goes beyond their usefulness in the material world ${ }^{5}$. In both Hardy's and Conrad's texts, a father fetishizes his daughter's footprint because he projects his own subjectivity and ambitions on her. Thus the footprint as "object-thing" is emblematic of patriarchal/colonial control, which commodifies Grace Melbury in The Woodlanders, and Nina Almayer in Almayer's Folly. But paternal fetishization is defeated by both daughters: Grace's light foot saves her from the mantrap set in her way, she is reconciled with her husband who takes her away from her father. Nina will not follow in her father's footsteps, she walks away from home and follows her desire. Both women free themselves from their footprint as "object-thing" and assert themselves as subjects.

Focusing on objects in Conrad and Hardy means raising the question of their texts as objets d'art - a question raised by several authors in this volume. Bernard shows how Hardy turns "objects of doom" into art objects, Le Saux sees the "magnifying of objects" as a way "to show the beauty of the insignificant". That point is also made by Grafe, who borrows from Tim Ingold a distinction between objects and things: to him poems are "things" rather than objects, i.e. phenomena "involved in setting, time, and process" (Grafe), which keep the poet in a permanent state of dynamism and creation. That idea brings desire back to the foreground, and is consonant with Lacan's statement that art objects are "sublime", in that they are "elevated to the dignity of the Thing" (Lacan 2008, 138). Could it not be argued that Conrad's novels are sublime objects because they are raised to the dignity of the "nothing" that they encircle? In both Hardy's and Conrad's writings, the void is turned to good account, for it makes resonant the silent voice of the text and makes audible its "unheard melodies".

\section{BIBLIOGRAPHY}

Barthes, Roland, Camera Lucida. Reflections on Photography (1980), trans. Richard Howard, New York: Hill \& Wang, 1981.

Brown, E.K., "The Art of the 'Crowded Novel”, in Charles Dickens, David Copperfield, ed. Jerome H. Buckley, New York: W.W. Norton, 1986.

Conrad, Joseph, Lord Jim (1900), Norton Critical Edition, New York: W.W. Norton, 1996. 
Lacan, Jacques, The Seminar, vol. XX, "On Feminine Sexuality, The Limits of Love and Knowledge, 1972-1973”, trans. Bruce Fink, New York: W.W. Norton and Company, 1999.

Lacan, Jacques, The Seminar, vol. VII, “The Ethics of Psychoanalysis, 1959-1960”, trans. Dennis Porter, Abingdon: Routledge, 2008.

Millgate, Michael (ed.), The Life of Thomas Hardy, London: Macmillan, 1984.

Woolf, Virginia, The Waves (1931), ed. David Bradshaw, Oxford World's Classics, 2015.

Žižek, Slavoj, The Sublime Object of Ideology, London: Verso, 1989.

Žižek, Slavoj, “Otto Weininger, or 'Woman Does Not Exist”, The Žižek Reader, eds. Elizabeth Wright \& Edmund Wright, Oxford: Blackwell, 1999.

\section{NOTES}

1. "Wandering between two worlds, one dead, / The other powerless to be born".

2. A parallel can be made between the convergence of the iceberg and the ship ("The Convergence of the Twain") and the chapter entitled "Converging Courses" ("Concurritur, Horae Momento") in Far from the Madding Crowd, in which a parody of kairos brings together the protagonists only to make them to burst apart (Lanone).

3. Like points of contact with the Lacanian Real (what cannot be integrated into the symbolic order and remains unspeakable)? The punctum is such a point of contact.

4. Objects seem to speak when characters are silent, they are also "witnesses" that have eyes to see. They could be linked to the two objects (gaze and voice) listed by Žižek.

5. If one remembers that for Lacan "jouissance is what serves no purpose" (Lacan 2008, 3), one feels tempted to argue that the "thingness" of objects is closely related to a subject's jouissance. And therefore not far removed from the Lacanian Thing, Das Ding.

6. Keats, "Ode on a Grecian Urn": "Heard melodies are sweet, but those unheard / Are sweeter". 